University of Nebraska - Lincoln

DigitalCommons@University of Nebraska - Lincoln

\title{
3-2013
}

\section{Modeling vulnerability of groundwater to pollution under future scenarios of climate change and biofuels-related land use change: A case study in North Dakota, USA}

\author{
Ruopu Li \\ University of Nebraska-Lincoln, rli3@unl.edu \\ James W. Merchant \\ University of Nebraska-Lincoln
}

Follow this and additional works at: https://digitalcommons.unl.edu/natrespapers

Part of the Environmental Indicators and Impact Assessment Commons, Hydrology Commons, Natural Resources and Conservation Commons, and the Water Resource Management Commons

Li, Ruopu and Merchant, James W., "Modeling vulnerability of groundwater to pollution under future scenarios of climate change and biofuels-related land use change: A case study in North Dakota, USA" (2013). Papers in Natural Resources. 368.

https://digitalcommons.unl.edu/natrespapers/368

This Article is brought to you for free and open access by the Natural Resources, School of at DigitalCommons@University of Nebraska - Lincoln. It has been accepted for inclusion in Papers in Natural Resources by an authorized administrator of DigitalCommons@University of Nebraska - Lincoln. 


\title{
Modeling vulnerability of groundwater to pollution under future scenarios of climate change and biofuels-related land use change: A case study in North Dakota, USA
}

\author{
Ruopu Li and James W. Merchant \\ Center for Advanced Land Management Information Technologies, School of Natural Resources, \\ University of Nebraska-Lincoln, 3310 Holdrege Street, Lincoln, NE 68583-0973, USA \\ Corresponding author — Ruopu Li, 3310 Holdrege Street Lincoln, NE 68583-0973, USA; \\ tel 402 472-4002, fax 402 472-2946, email rli3@unl.edu
}

\begin{abstract}
Modeling groundwater vulnerability to pollution is critical for implementing programs to protect groundwater quality. Most groundwater vulnerability modeling has been based on current hydrogeology and land use conditions. However, groundwater vulnerability is strongly dependent on factors such as depth-to-water, recharge and land use conditions that may change in response to future changes in climate and/or socio-economic conditions. In this research, a modeling framework, which employs three sets of models linked within a geographic information system (GIS) environment, was used to evaluate groundwater pollution risks under future climate and land use changes in North Dakota. The results showed that areas with high vulnerability will expand northward and/or northwestward in Eastern North Dakota under different scenarios. GIS-based models that account for future changes in climate and land use can help decision-makers identify potential future threats to groundwater quality and take early steps to protect this critical resource.
\end{abstract}

Keywords: groundwater vulnerability, climate change, land use change, biofuels, nitrate, North Dakota

\section{Introduction}

Globally, at least two billion people depend upon groundwater as the principal source of their drinking water (National Research Council, 2008; Sampat, 2000). Dependence upon groundwater is especially great in areas such as Northern China, Eastern Europe, Northern India and the U.S. Great Plains. Recent forecasts suggest that the combined effects of population growth, global warming and land use change will, in the near future, lead to even greater reliance on groundwater for public water supply (Rosenzweig et al., 2007; Hall et al., 2008).

Resource managers are increasingly concerned about human health and ecological effects of contaminants such as nitrates and pesticides (National Research Council, 2008; Sampat, 2000; Merchant, 1994). The application of fertilizer and pesticides on croplands, for example, has often been shown to result in deterioration of the quality of drinking water and increasing health concerns, such as blue baby syndrome, gastric cancer and non-Hodgkin's lymphoma (Knobeloch et al., 2000; Karkouti et al., 2005). Since detection, monitoring and treatment of groundwater pollution are relatively cost-prohibited; management of groundwater quality has emphasized protection of the resource (i.e., prevention of contamination). Protection strategies, however, need to be targeted so that staff, funds and technology can be focused upon those areas that are most threatened (Merchant, 1994). Today it is recognized that targeting must be based upon reliable forecasts of the risk of groundwater pollution under a variety of possible future climate/socioeconomic/land use scenarios (Twarakavi and Kaluarachchi, 2006).

During recent decades, a variety of methods for modeling and mapping groundwater vulnerability have been developed (see, for example, National Research Council, 1993; Gogu and Dassargues, 2005; Focazio et al., 2005). These models typically involve the analysis of the inter-relationships between key hydrogeologic characteristics (e.g., depth-to-water, soils, aquifer hydrogeology, and groundwater recharge). Although groundwater vulnerability models generally consider similar factors, the models employ different approaches for data integration and analysis. These can be grouped into three categories: index methods (Aller et al., 1985), statistical procedures (Nolan et al., 2002; Masetti et al., 2009), process-based methods (Neukum and Azzam, 2009) and/or a combination of 
these methods (Yu et al., 2010). One of the groundwater vulnerability models used most often is "DRASTIC". The model is formulated as a weighted sum of hydrologic factors that are related to the movement of pollutants from the ground surface to aquifers (Aller et al., 1985). The model's simple formulation and the ease of integration with geographic information systems (GIS) make it wellsuited for regional analyses of groundwater pollution potential. Another significant advantage of DRASTIC is its flexibility as it can be adapted to incorporate other factors (Rahman, 2008; Lima et al., 2011), such as land use and land cover (LULC), a factor important in assessing impacts of contaminants such as farm chemicals on groundwater quality (Eckhardt and Stackelberg, 1995; Scanlon et al., 2007).

The DRASTIC model is usually implemented based on "static" conditions, i.e., the model assesses vulnerability for a single point in time based on current hydrogeologic and LULC conditions (Butscher and Huggenberger, 2009). However, groundwater vulnerability is strongly dependent on factors such as depth-to-water table, recharge and LULC conditions, all of which are influenced by climate conditions and human activities. Groundwater quality is expected to respond to changes in climate and anthropogenic activities due primarily to the influences of recharge and land use on groundwater systems (Green et al., 2011). Climate change can potentially alter the vulnerability of shallow aquifers by affecting depth-to-water table and recharge (Pointer, 2005; Scibek and Allen, 2006; Toews and Allen, 2009). And, human activities such as changes in LULC can also affect groundwater vulnerability. It has been forecasted that agricultural land use, and associated application of farm chemicals, may change quite significantly as a result of global warming and/or changing socio-economic circumstances such as increasing demands for biofuels (Ojima et al., 1999; Foley et al., 2004; National Research Council, 2008). Elevated grainbased bioethanol demands may lead to expansion of corn production and increased use of nitrogen-based fertilizers (Simpson et al., 2008). As a result, in some locations there could be concomitant, though currently unknown, changes in risks of groundwater pollution (Dams et al., 2007; Graham, 2007).

Previous studies have shown that the vulnerability of groundwater may vary over time due to changing climate and/or LULC. For example, Ducci (2005) demonstrated that patterns of regional groundwater pollution vulnerability will vary between drought, average, and wet climatic conditions. Butscher and Huggenberger (2009) analyzed a karst aquifer system in Switzerland based on a lumped parameter model and found that groundwater vulnerability depends on climate-affected recharge conditions. Lima et al. (2011) predicted future groundwater vulnerability based on a modified DRASTIC model and future agricultural expansion scenarios simulated by Dyna-CLUE model. However, no investigation has yet focused on groundwater vulnerability that may be affected by both climate and LULC change especially at the regional level. Decision-makers need tools to identify "hotspots" of high groundwater vulnerability in order to facilitate allocation of resources for groundwater protection.

The U.S. northern Great Plains is characterized by high natural variability of climate, highly fertile soils and widespread agricultural land use. During the 20th century, the average temperature of this region rose by more than $1{ }^{\circ} \mathrm{C}$, with increases up to $3{ }^{\circ} \mathrm{C}$ observed in parts of North Dakota and South Dakota (U.S. Global Change Research Program, 2000). Precipitation has also increased over most of the region (U.S. Global Change Research Program, 2000). It is expected that average temperature will continue to rise into the 21 st century (up to around $3{ }^{\circ} \mathrm{C}$ in the mid21 st century), and increasing precipitation is also expected to occur in many areas (up to about $6 \mathrm{~cm}$ in the mid-21st century) (IPCC, 2007). Meanwhile, there has also been significant LULC change in the region. The U.S. Department of Agriculture (USDA) has documented that, during the period 2000-2009, thousands of acres in other crops were converted to corn production in the northern Great Plains (Wallander et al., 2011). It has been projected that agricultural land use will continue to expand as a result of increasing demands for biofuels and global warming (Ojima et al., 1999; Foley et al., 2004; National Research Council, 2008). Biofuel crops (i.e. corn and soybeans) are expected to dominate the future agricultural landscape of the northern Great Plains as a result of (1) increasing demands for bioethanol stemming from the federal Renewable Fuel Standard (RFS) (Brooke et al., 2009); and (2) increasing suitability for biofuel crops that prefer a warmer climate and longer growing season. It has also been noted, however, that shifts in climate and land use patterns may result in a range of potentially negative environmental consequences including elevated groundwater pollution risks (de Oliveira et al., 2005; Kennedy, 2007).

This research presents a modeling approach that integrates groundwater vulnerability, climate change scenarios, and modeled LULC scenarios essential for future water quality management in North Dakota, a northern Great Plains state. The objective is to determine if, how and where the vulnerability of groundwater to pollution in this area may be impacted by projected land use change driven by both climate change and increasing demands for biofuels. In this study, the focus is on the vulnerability of groundwater to pollution from nitrates, a constituent of chemical fertilizers used widely in the U.S. Great Plains and known to have implications for human health (Power and Schepers, 1989).

\section{Methods}

\subsection{Study area}

North Dakota was selected as the study area because it is representative of the northern Great Plains, a region that has been experiencing significant changes in both climate and land use. The state has a continental climate typified by cold winters and hot summers. As noted above, however, during the past century average temperatures in North Dakota have increased up to $3{ }^{\circ} \mathrm{C}$ (U.S. Global Change Research Program, 2000), among the highest in the northern Great Plains. Apart from climate change, North Dakota is also experiencing land use changes driven by demand for biofuels. At least fifteen incentive programs, laws and regulations are in place to govern the production, transportation and sale of biofuels (U.S. Department of Energy, 2011). And, North Dakota has joined with northern Great Plains states such as South Dakota, Nebraska and Iowa under the Energy Security and Climate Stewardship Platform to create a regional biofuels corridor program; see http:// www.midwesterngovernors.org/resolutions/Platform.pdf.

North Dakota spans four principal ecoregions (Figure 1): the Lake Agassiz plain, the Northern Glaciated Plains, the Northwestern Glaciated Plains, and the Northwestern Great Plains (the figure were produced based on Omernik, 1987). The Lake Agassiz Plain, situated along the eastern edge of the state, features highly fertile soils and includes the most productive farmlands in the state. The regions west of the Lake Agassiz Plain gradually rise in elevation and have lower soil fertility. North Dakota is the leading producer of wheat, barley, sunflowers and dry edible beans in the U.S. By 2009, however, the three most important farm commodities changed to wheat, soybeans and corn at 29.4\%, $16.1 \%$ and $12.7 \%$, respectively (Economic Research Service, 2011).

Groundwater in North Dakota occurs in two major rock types, unconsolidated beds of gravel, sand, silt and/or clay and the underlying bedrocks. The most productive aquifers were formed by fluvial unconsolidated deposits and distributes along the surface drainage system with well yields between 0.19 and $1.9 \mathrm{~m}^{3} / \mathrm{min}$ (Paulson, 1983). Away from the major fluvial aquifers, those unconsolidated minor aquifers, although occurring with smaller well yields, can generally meet the rural domestic needs. Bedrock aquifers are another important water source. These aquifers are mostly confined, 
Figure 1. Major ecoregions of North Dakota. The map was generated from U.S. Environmental Protection Agency (EPA) Level III Ecoregions (Omernik, 1987) and the U.S. Geological Survey (USGS) National Hydrography Dataset.

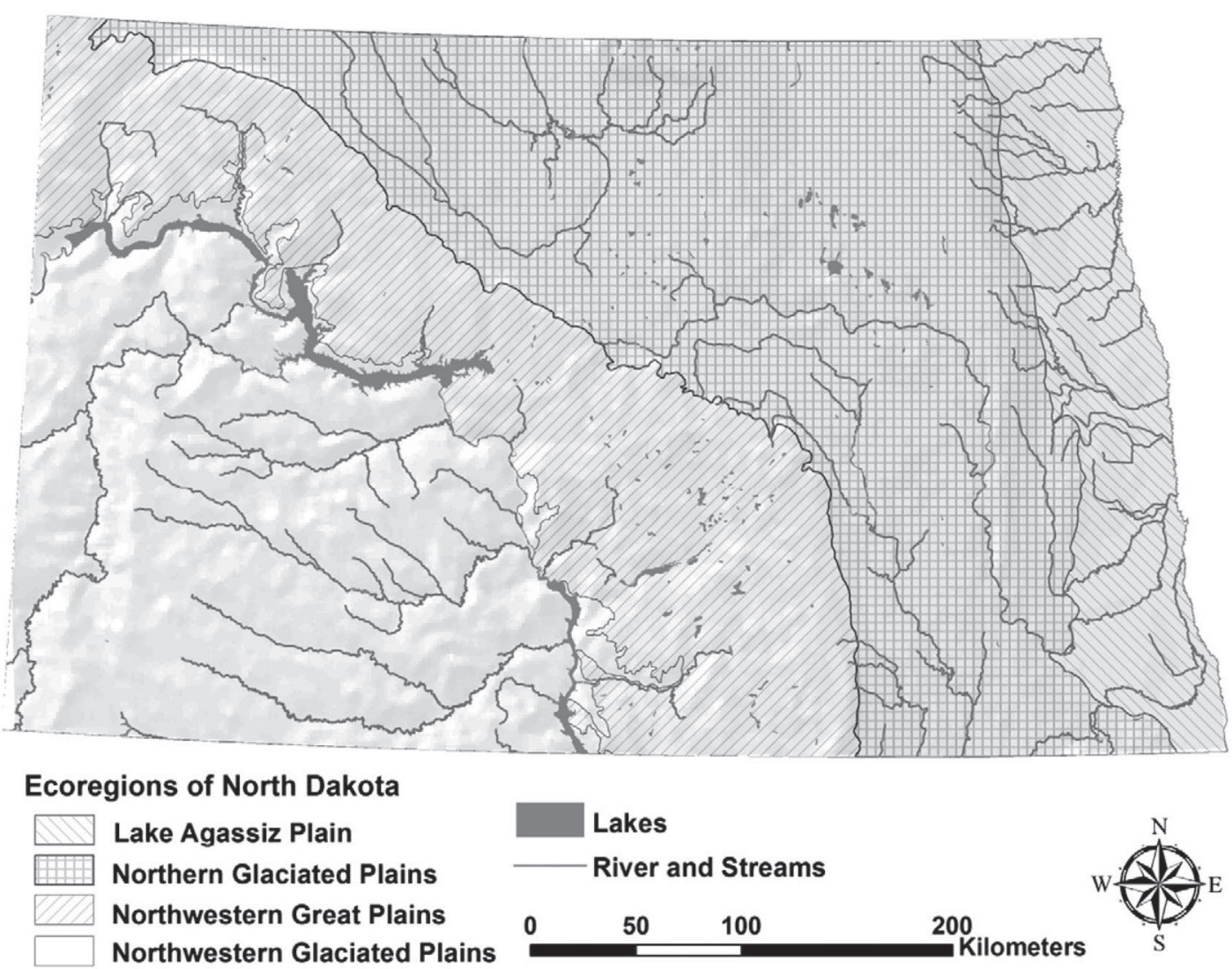

but are generally unsuitable for many uses due to widespread salinity. In this paper, we give most attention to unconsolidated and unconfined aquifers due to our focus on nitrate contamination.

\subsection{General modeling framework}

Three sets of models, linked within a GIS environment (Figure 2), were used to forecast groundwater vulnerability for two future periods (years 2020 and 2050) under three scenarios proposed by the Intergovernmental Panel on Climate Change (IPCC) Special Report on Emission Scenarios (SRES). The following subsections (2.3-2.8) summarize the development of: (1) future climate change scenarios, (2) future biofuels-related land use scenarios, (3) future groundwater recharge and groundwater level, and (4) future regional groundwater pollution risk. All geospatial modeling was implemented using ArcGIS (Version 9.3.1) software. Geospatial data were converted to raster format at a resolution of $1500 \mathrm{~m}$, a cell size approximating the size of a crop section in North Dakota.

Scenarios proposed by the Intergovernmental Panel on Climate Change (IPCC) Special Report on Emissions Scenarios (SRES) were used for modeling (Nakicenovic et al., 2000). The SRES scenarios have been widely applied in climate change impact and adaptation studies conducted worldwide (Ruosteenoja et al., 2003). Three specific scenarios were employed in this study: B1, A2 and A1B. All have been used with particular frequency by the climate change research community (Meehl and Hibbard, 2007). It should be noted that the SRES scenarios exclude catastrophic futures, such as large scale economic and environmental collapse.

\subsection{Climate change scenarios}

The B1, A2 and A1B scenarios provided the foundation for the climate change projections in this study. An ensemble of averaged statistically downscaled future climate change projections from
16 fully-coupled atmosphere-ocean general circulation models (AOGCMs) such as CCSM3.0, GFDL_CM2.1, and HadCM3.0, were obtained from Green Data Oasis (Maurer, et al., 2007). This archive contains a dataset of monthly temperature and precipitation projections during 1950-2099 over the contiguous United States at a 0.125 -degree resolution. The original projections were generated from the World Climate Research Programme's (WCRP's) Coupled Model Intercomparison Project phase 3 (CMIP3) multimodel dataset as referenced in the IPCC Fourth Assessment Report (Meehl et al., 2007). These data are typically produced and stored in netCDF or binary format, a format that cannot be directly utilized for spatial analysis in ArcGIS. It was, therefore, essential to convert these data into a GIS-compatible format for further analyses.

Average temperature and precipitation projection for the years 1971-2000 (baseline period), 2020s (near period) and 2050s (distant period) in ASCII format were converted to GeoTIFF format in batch by running Python programming codes using FWTools 2.4.6. Historical observed precipitation and temperature data (1971-2000) were downloaded from the PRISM Climate Group $<$ http://prism.oregonstate.edu/ >, which provides high-quality historical climate data in grids. These data were resampled at $1500 \mathrm{~m}$, a resolution consistent with the land use factor layer (see Section 2.4). Future regional climate conditions were estimated as the historical observed climate data multiplied by the ratio of future climate projection divided by the baseline climate projection, because these physically-based climate models provide more accurate estimates of ratios and differences (scaling factors) from baseline to predicted scenarios (Loaiciga et al., 1996).

\subsection{Future Biofuels-related land use change}

In this study, corn and soybeans were considered to be "biofuels-related" LULC types because of their importance as bioethanol and 


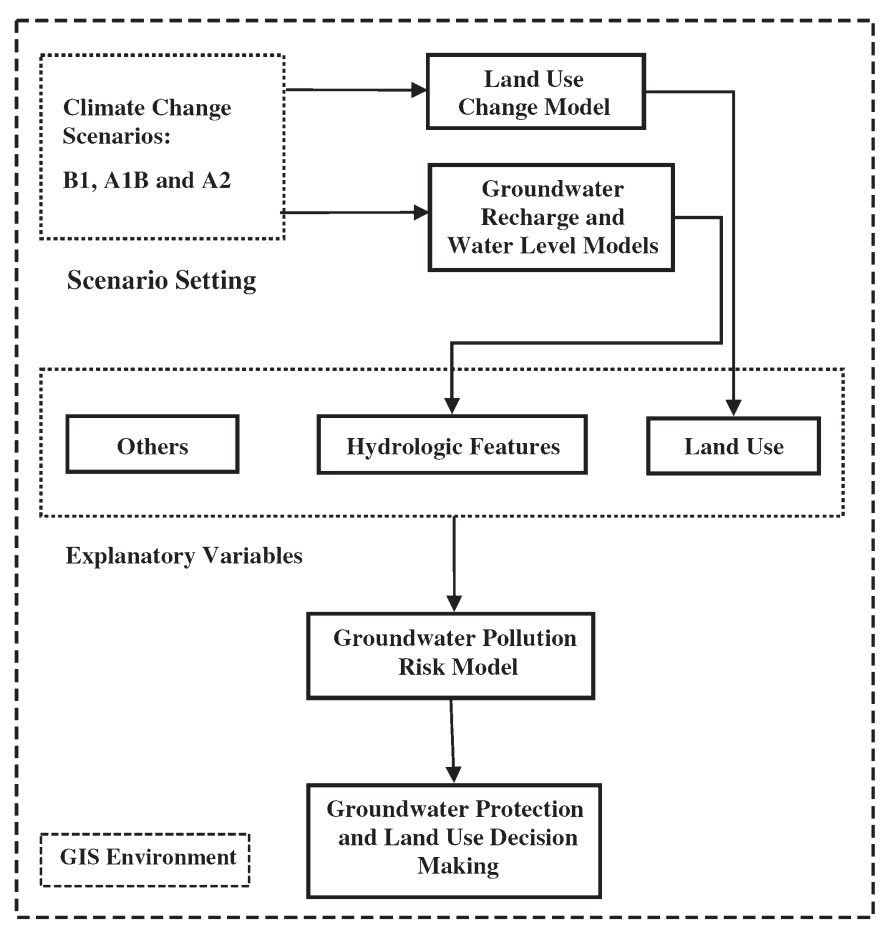

Figure 2. General modeling framework for model integration.

biodiesel feedstocks. Future change in biofuels-related LULC was modeled using linked "quantity" and spatial allocation modules (the model framework was adapted based on Li et al., 2012) (Figure 3). The quantity module was employed to determine, and subsequently forecast, the total amount of change in corn/soybean cropland (i.e., the number of cells of other LULC types to be transformed into corn/soybeans). A spatial allocation module was then used to spatially distribute the projected changes (i.e., to determine which specific cells in the map grid to change from one LULC type to another).

It was assumed that future expansion of biofuel crops would occur first on lands having soils and climate most suitable for crop production and thereafter occur on lands less suitable. The three SRES scenarios and corresponding climate change projection were used to guide modeling of future biofuels-related cropland change. Due to the qualitative nature of the SRES scenarios, they cannot be directly converted into quantitative data on biofuel crops. The following interpretation is based on the IPCC SRES report (Nakicenovic et al., 2000).

- The B1 scenario envisions a future world having a high level of environmental and social consciousness combined with concerted global efforts towards sustainable development. This world use technology to achieve reductions in conventional energy usage, and exhibits increasing usage of biofuels and wind energy. Under the B1 scenario, biofuel crops may expand rapidly to meet increasing demands for bioethanol and biodiesel fuels. Additionally, in this scenario demographic pressure is relatively low, and increases in food demands can be readily met by increasing productivity. Thus, more agricultural lands may be devoted to biofuel crops without affecting food safety. The B1 scenario represents the fastest pace of biofuels-related land use change.

- The A2 scenario is characterized by high demographic pressure, more limited environmental concerns, and high use of fossil fuels and nuclear energy. With rapid increase in population, arable lands are primarily used to produce food rather than biofuels. With the emphasis on food security, economic incentives for the biofuel industry are less likely to continue. Land use change

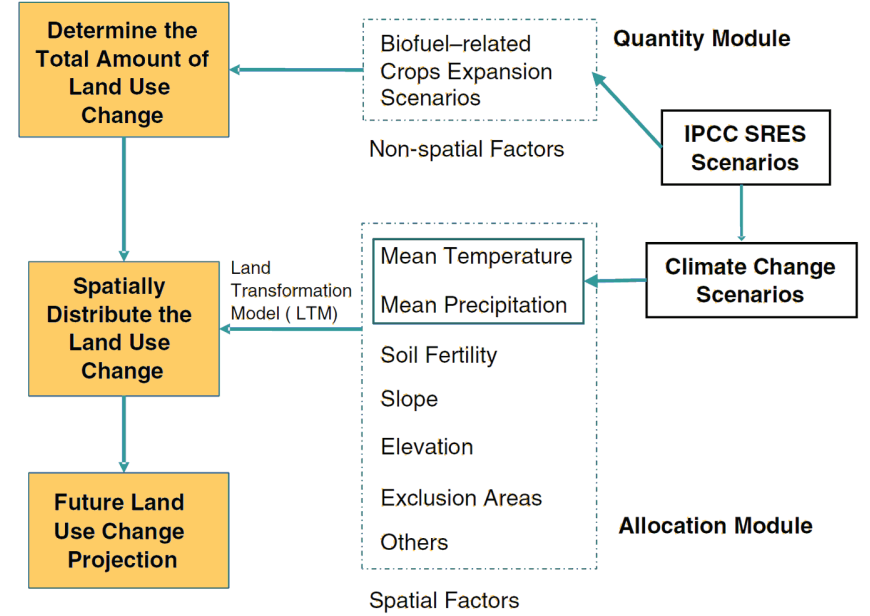

Figure 3. Framework to model biofuels-related land use change in response to different scenarios. The framework was based on Figure 3 in Li et al., 2012).

driven by biofuels demands may diminish. The A2 scenario represents the slowest pace of biofuels-related land use change.

- The A1B scenario assumes a balance between conventional and new energy sources. It takes an intermediate position between the two extremes described by the respective storylines of the B1 and A2 scenarios (Nakicenovic et al., 2000). Thus, the A1B scenario represents a moderate pace of biofuels-related land use change.

Estimates of future biofuels-related land use change were made by combining the narrative descriptions of SRES scenarios (summarized above) with statistical extrapolation based on historical trends in crop acreages obtained from the National Agricultural Statistics Service (2010). It was assumed that the current high rate of increase in corn/soybean land will gradually slow due to factors such as increasing competitive use of corn/soybeans for food and biofuels. S-shaped logistic growth models approximate the above growth pattern. Three logistic models, SLogistic1, SRichards1 and Five Parameter Logistic, were used to develop projections of future biofuels-related cropland. These formulas were assumed to project potential areal increases of biofuel crops with highest, lowest and median increase rates corresponding with the B1, A2 and A1B scenarios in the year 2020 and year 2050 (Figure 4). It was also assumed that the urban area would remain static during the modeling period since the urban area in North Dakota did not expand notably during the past few decades; see http://www.citypopulation.de/php/usa-metro.php .

The Land Transformation Model (LTM) was used to distribute the forecasted LULC change over the state of North Dakota. The model essentially generates a suitability map for croplands, and then selects the cells exhibiting the highest suitability to convert. Six environmental variables were chosen as the driving factors for biofuel cropland modeling in North Dakota: terrain elevation, terrain slope, soil organic matter, Cation Exchange Capacity (CEC) of the soil, mean precipitation (1971-2000), and mean temperature (1971-2000). All are important to establishing the suitability of land for supporting crops (e.g., Bowen and Hollinger, 2002; Kravchenko and Bullock, 2000). National Agricultural Statistics Service (NASS) Cropland Data Layers (CDLs) for North Dakota < http://www.nass.usda.gov/research/Cropland/SARS1a.htm > were used to map historic cropland change, because they provide specific cropland information for North Dakota over a relatively long time period (8-13 years). In addition, exclusionary zones (e.g. urban lands, wildlife protection areas, and water bodies) where future cropland growth would be prohibited were established. It was assumed that cropland used for "non-biofuels" crops remained relatively static during the modeled time 


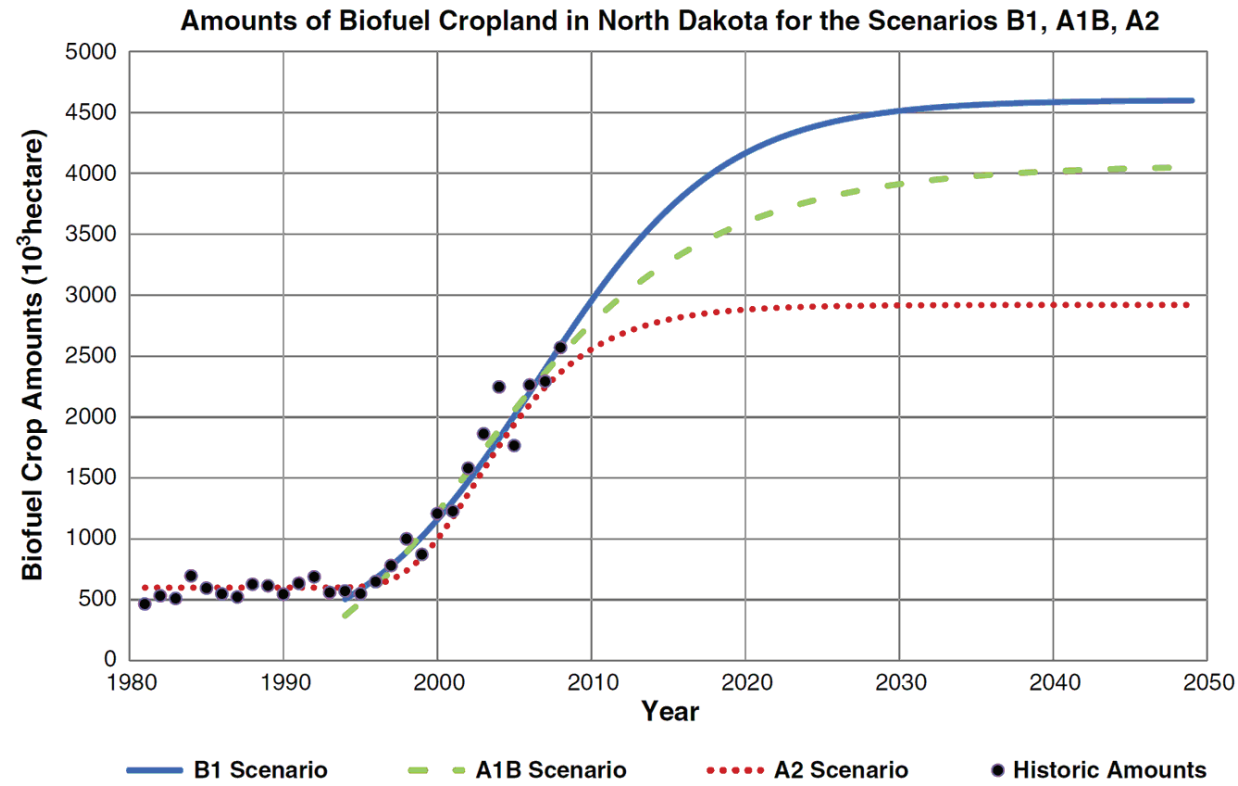

Figure 4. The amounts of biofuels-related cropland in North Dakota between 1980 and 2050. The figure is based on agricultural statistical data from the National Agricultural Statistics Service (2010).

period (2000-2050); thus, modeling focused only on areas replaced by corn/soybeans.

The model was calibrated and validated using $30 \mathrm{~m}$-resolution land use data obtained from the North Dakota CDLs for the years 1999, 2000, 2004, 2005, 2010 and 2011. Details on the implementation of the model were available at $\mathrm{Li}$ et al. (2012). Areal estimates of biofuel crops for the B1, A2 and A1B scenarios provided in the quantity module and corresponding climate change scenarios (i.e. precipitation and temperature) were then plugged into the calibrated model to calculate the future distributions of biofuel crops.

\subsection{Future groundwater recharge affected by climate change}

A number of studies have indicated that climate change can affect groundwater recharge (Eckhardt and Ulbrich, 2003; Holman, 2005; Scibek and Allen, 2006). Increases in precipitation, for example, would generally be expected to produce greater aquifer recharge rates (Rosenzweig et al., 2007). Many modeling techniques have been used to determine the potential impacts of climate change on groundwater recharge. These include soil-water balance models (Arnell, 1998; Scibek and Allen, 2006; Toews and Allen, 2009), empirical models (Chen et al., 2002), and distributed models (Croley and Luukkonen, 2003; Eckhardt and Ulbrich, 2003). However, these methods are generally technically complex and unsuitable for large regional analyses since the data on key physical parameters are usually not available.

In this study, the percolation index (PI) method was used to estimate future average annual water flow through the soil (Williams and Kissel, 1991; Braun et al., 2003; Hamza et al., 2007). The equations used to calculate recharge are as follows in Equation (1) :

$$
\begin{array}{ll}
\text { Hydrologic Group } & \text { Equations } \\
A & \mathrm{PI}=(\mathrm{P}-10.28)^{2} \div(\mathrm{P}+15.43) \\
B & \mathrm{PI}=(\mathrm{P}-15.05)^{2} \div(\mathrm{P}+22.57) \\
C & \mathrm{PI}=(\mathrm{P}-19.53)^{2} \div(\mathrm{P}+29.29) \\
D & \mathrm{PI}=(\mathrm{P}-22.67)^{2} \div(\mathrm{P}+34.00)
\end{array}
$$

where PI is the percolation index (inches/year), $\mathrm{P}$ is the precipitation (inches/year), and $A, B, C$ and $D$ are hydrologic soil groups (soil map units having similar physical and runoff characteristics). All units were converted from English to metric equivalents. In
North Dakota, 99\% of agricultural croplands are not irrigated (Jia et al., 2007); therefore irrigation was not considered in this research. Based on Equation (1), future groundwater recharge was estimated using precipitation from the precipitation projection dataset and the hydrologic soil groups. The spatial distribution of hydrologic soil groups was derived from the U.S. General Soil Map (STATSGO) using the Soil Data Viewer < http://soils.usda.gov/sdv/ > developed by USDA.

\subsection{Future depth-to-water (DTW) conditions}

DTW, defined as the distance from the ground surface to the water table, impacts the time required for contaminants to reach the water table. As DTW increases, the probability of groundwater pollution generally decreases. DTW levels are controlled by the balance among recharge to, storage in, and discharge from an aquifer Forecasting the DTW in response to climate change usually requires complex numerical modeling (Yang and Xie, 2003; Scibek and Allen, 2006), which also involves considerable uncertainties related to downscaled climate models, aquifer heterogeneity, and other parameters (Scibek and Allen, 2006). Modeling can be complicated by groundwater pumping for irrigation as well as industrial and residential demands (Bates et al., 2008). In this study, changes in DTW were estimated using the water-table fluctuation (WTF) method, a procedure that relates changes in water-table level measured in unconfined aquifers with recharge water arriving at the water table (Rasmussen and Andreason, 1959). The method is implemented with an equation-Equation (2) — expressed as:

$$
\Delta \mathrm{R}\left(\mathrm{t}_{\mathrm{j}}\right)=\mathrm{S}_{\mathrm{y}} \times \Delta \mathrm{H}\left(\mathrm{t}_{\mathrm{j}}\right)
$$

where $R\left(t_{j}\right)$ is recharge occurring between initial time $t_{0}$ and ending time $t_{j}, S_{y}$ is specific yield (dimensionless), and $\Delta \mathrm{H}\left(\mathrm{t}_{\mathrm{j}}\right)$ is the peak water level rise attributed to the recharge period. The specific yield is defined as the ratio of the volume of water that will yield by gravity to the total volume of saturated soil or rock (a dimensionless value). It is assumed that long-term DTW fluctuations, over periods of decades, can be attributed to changes in recharges due to climate alteration. The water-table change in North Dakota was estimated using the projected increase of recharge and specific yield. The specific yield in North Dakota was estimated to be approximately 0.15 (Burkart, 1981; Schuh and Patch, 2009). 
The DTW for the current period $\left(t_{0}\right)$ was modeled using data extracted from, respectively, the USGS Active Groundwater Level Network and the North Dakota State Water Commission Surface and Ground Water Data Portal: http://www.swc.state. nd.us/4dlink2/4dcgi/wellsearchform/Map\%20and\%20Data\%20 Resources. The data were retrieved using a web query function of Microsoft Excel and stored in Excel spreadsheets. Locations of surface water features, such as major streams, lakes, wetlands, and springs were obtained from the USGS National Hydrography Dataset (NHD) and used to indicate where the DTW approximates 0 (Snyder, 2008). ArcGIS was used to randomly plot 1000 points (where the DTWs are 0) on these surface water features. The DTW surface was estimated based on an integration of interpolated water table depth and water table elevation, a method proposed by Snyder (2008).

\subsection{Other factors}

Several other factors were used to model groundwater pollution risk. These included soil characteristics, topography (slope) and the characteristics of the vadose zone. These factors were considered static in this study.

\subsubsection{Soils data layer for North Dakota}

Soils serve as the dominant sink for retention of nitrate (Barrett and Burke, 2002), and impact the leaching of nitrate to deeper horizons. In this study, five soil properties were extracted from the U.S. General Soil Map (STATSGO) to represent nitrate attenuation property. These were the percentages of sand, silt and clay, saturated hydraulic conductivity (Ksat), and organic matter contents (OM). A factor analysis was conducted to reduce the collinearity among the soil characteristics (Ige et al., 2007), and produce a "soil index" indicative of the groundwater pollution attenuation property of the soil-Equation (3):

$$
\begin{aligned}
\text { Soil }_{\text {Index }}= & -0.294 \text { Sand }+0.262 \text { Clay }+0.256 \text { Silt } \\
& +0.138 \text { OM }-0.257 \text { Ksat. }
\end{aligned}
$$

The first component was observed to account for most of the total variance (71\%), and therefore this component was used to represent the composite soil characteristics in subsequent research. The soil index is positively correlated with organic matter and percentage of silt and clay, but negatively associated with the saturated hydraulic conductivity and the percentage of sand. Finally, a map layer of the soil index was developed. A higher index value indicates higher nitrate attenuation potential, and vice versa.

\subsubsection{Slope data layer for North Dakota}

Slope affects the likelihood that a contaminant deposited on the land surface will infiltrate through the soil. As slopes become increasingly steep, pollutants are more likely to run off than to seep into the subsurface (Aller et al., 1985). Slopes were derived from the $30 \mathrm{~m}$ National Elevation Dataset: http://seamless.usgs.gov/.

\subsubsection{Impact-of-the-vadose-zone (IVZ) data layer for North Dakota}

Characteristics of the vadose zone, the unsaturated area below the soil and above the unconfined water table, are important for assessing nitrate attenuation processes such as biodegradation, chemical reaction, volatilization and dispersion. Silt and clay in the vadose zone can increase the time and/or opportunities for attenuation. The thickness of silt and clay in the vadose zone was used as an indicator of the impact of the vadose zone on nitrate attenuation. This factor was derived from lithologic records in the Surface and Ground Water Data Portal administered by the North Dakota State Water Commission. Lithologic descriptions for each record were reclassified into one of six groups: silt/clay, sand/gravel, sand/silt/clay, sandstone/limestone, bedrock and other hard materi- als (such as shale and lignite). The percentage of silt/clay was computed by dividing the accumulated thickness of silt/clay above the water table by the DTW in each test hole. The DTW in each testhole location was queried from the DTW map layer. The percentages of silt/clay in test holes were interpolated using kriging to a surface for the study area. Finally, the thickness of silt/clay in IVZ was generated by multiplying the layers of silt/clay percentage in the IVZ and DTW.

\subsection{Groundwater vulnerability modeling}

A revised DRASTIC model, DRSTIL (Equation (4)), was employed to model groundwater vulnerability. Each of the DRSTIL factors (Depth-to-water table, Recharge (net), Soil media, Topography, Impact of the vadose zone, Land use) was assigned ratings and a numerical weighting to reflect its relative importance in estimating groundwater pollution potential. Ratings are intended to reflect the relative significance of data values (mapped "classes") within each factor (Merchant, 1994). For example, locations where the water table is deep below the surface are assumed to be less vulnerable to pollution than locations where the water table is shallow because, all other things being equal, the greater depth-to-water should indicate lower likelihood of contaminants reaching an aquifer. Therefore, areas having greater depth-to-water are assigned a lower numerical rating than locations with a shallower water table. All factors were assigned ratings on this basis (see Aller et al., 1985). The ratings for the land use factor were assigned based on the nitrate fertilizer application recommended for different crops in North Dakota (Franzen, 2009) (Table 1).

A departure from the standard approach to assignment of DRASTIC ratings was adopted for this research. The ratings for each factor layer were assigned by normalizing the grid values of the layer to a $0-1$ scale. For factors with larger values indicating higher pollution potentials (e.g. recharge and land use), the ratings were calculated using the following approach: $(\mathrm{V}-\min \mathrm{V}) /(\max \mathrm{V}-\min$ $\mathrm{V}$ ), where $\mathrm{V}$, $\min \mathrm{V}$ and $\max \mathrm{V}$ represent the values, minimum values and maximum values of the factors in the dataset under different periods. This approach allows derived vulnerability scores for different periods comparable by using the same data range. For factors with smaller values corresponding to higher pollution potentials (e.g. DTW, soil, topography and impact-of-vadose-zone), the ratings were normalized as: $(\max V-V) /(\max V-\min V)$.

Table 1. Ratings for different land use and land cover types.

\begin{tabular}{lll}
\hline Crop type & $\begin{array}{l}\text { Soil nitrate plus } \\
\text { fertilizer nitrate } \\
\text { required (pound/acre) }\end{array}$ & Ratings \\
\hline Alfalfa & 0 & 0 \\
Barley & 160 & 0.68 \\
Canola & 150 & 0.64 \\
Corna & 235 & 1 \\
Dry edible beans & 80 & 0.34 \\
Pasture/range & 50 & 0.21 \\
Potatoes & 200 & 0.85 \\
Sorghum & 132 & 0.56 \\
Soybeans & & 1 \\
Sugar beets & 0 & 0.55 \\
Sunflower & 130 & 0.53 \\
Spring and durum wheat & 125 & 0.21 \\
Safflower & 50 & 0.43 \\
Water/wetlands & 100 & 0 \\
Urban/barren & 0 & 0 \\
Woodland/shrubland & 0 & 0
\end{tabular}

a. Corn and soybeans, typically grown in rotational cycles, present similar or even higher contaminant leaching potentials to continuous corn (Zhu and Fox, 2003; Klocke et al., 1999; Randall et al., 1997), although soybeans can fix nitrogen and do not require fertilizer input. Continuous corn production may create smaller annual percolation below the root zone when compared corn-soybeans rotations (Thomas et al., 2009). 


\section{Biofuel Crop Distribution in North Dakota for the Scenarios B1, A2, and A1B in Future Periods (Year 2020 and Year 2050)}

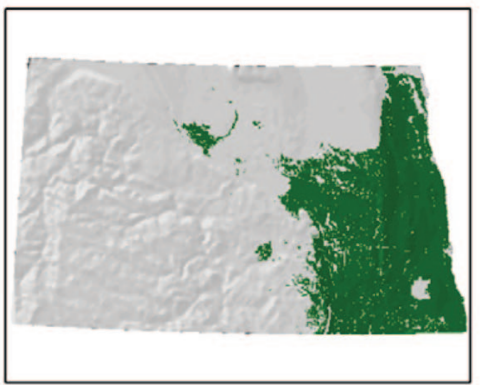

B1: Year 2020

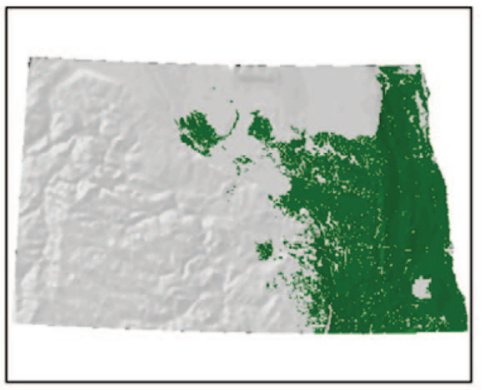

B1: Year 2050

Biofuel Crops

Other Land Types

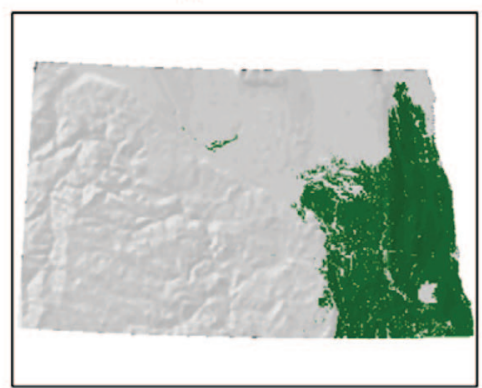

A1B: Year 2020

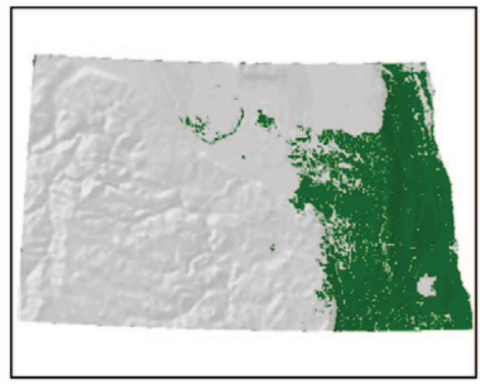

A1B: Year 2050

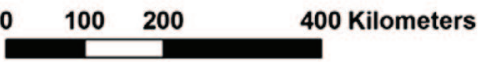

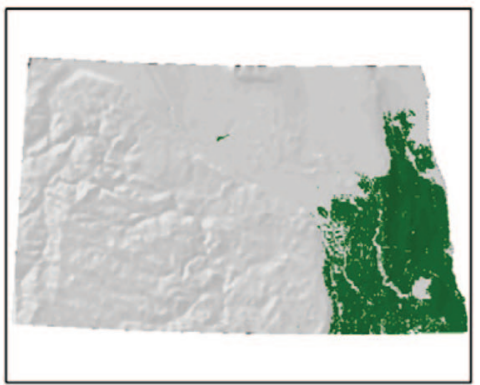

A2: Year 2020

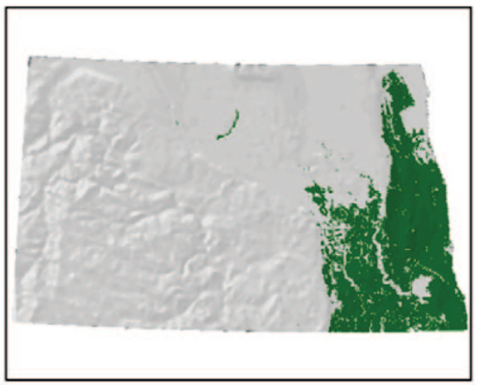

A2: Year 2050

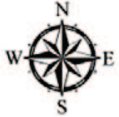

Notes: Biofuel Crops are referred to as corn and soybeans.

Figure 5. Projected biofuels-related land use change in North Dakota.

GroundwaterVulnerabilityScore $=D_{R} D_{W}+R_{R} R_{W}+S_{R} S_{W}$

$$
+T_{R} T_{W}+I_{R} I_{W}+L_{R} L_{W}
$$

where

R: Rating

$W:$ Weight

D: Depth to water

R: (Net) Recharge

S: Soil media

T: Topography (slope)

I: Impact of the vadose zone

$L$ : Land use

Weights were assigned to each factor following guidelines given in the DRASTIC documentation (Aller et al., 1985). Aller et al. (1985) proposed two approaches for weighting the factors in DRASTIC: a pesticide and a general version. Pesticide weights were designed to reflect the processes that most affect pesticide transport into the subsurface with particular focus on soil (Aller et al., 1985; Frederick, 1991). General DRASTIC weights were recommended for use in studying other potential pollutants such as application of fertilizers (Frederick, 1991). Since the focus of this research is on the vulnerability of groundwater to pollution from nitrates, the weightings for each factor were derived from those developed for the general DRASTIC (Table 2). Although land use was not included in the original DRASTIC model, it was assigned the largest weight due to its direct relationship with nitrate pollutant loadings.

\section{Results and discussion}

\subsection{Future land use scenarios}

Areas planted to corn and soybeans, crops often used for biofuels, are projected to expand northward and northwestward under all future scenarios (see Figure 5). Table 3 shows the areal differences in the biofuels-related cropland between different SRES scenarios
Table 2. Weights of the DRSTIL factors.

\begin{tabular}{ll}
\hline Factor & Weight \\
\hline Depth-to-water & 5 \\
Recharge & 4 \\
Soil & 2 \\
Topography & 1 \\
Impact of the vadose zone & 5 \\
Land use & 5 \\
\hline
\end{tabular}

and ecoregions in North Dakota. The time period of the baseline scenario is set as 2000. In general, the B1, A2 and A1B scenarios all suggest expansion of biofuels-related cropland between the years 2020 and 2050 in the Lake Agassiz Plain and Northwestern Glaciated Plains. In the Northern Glaciated Plains, while B1 and A1B scenarios indicate expanding trend of biofuels-related cropland between the years 2020 and 2050, a reduction of biofuels-related cropland is observed under the A2 scenario (Table 3). This apparent anomaly may be attributed to potentially reduced land suitability for biofuels-related crops affected by future climate change. In the Northwestern Great Plains, no biofuels-related cropland was projected for the years 2020 or 2050.

The greatest increases in biofuels-related cropland are projected to occur in the Lake Agassiz Plain and Northern Glaciated Plains ecoregions (Table 3). Compared with other regions of North Dakota, these two ecoregions feature fertile soils, lower elevations, generally warmer temperatures and abundant precipitation, and thus present the highest suitability for the cultivation of biofuel crops. The largest area of cropland development is projected to occur under the B1 scenario, while the A2 scenario shows the fewest hectares of LULC change. This difference can be attributed to the differing assumptions of future demands for cleaner en- 


\section{Changes in Groundwater Recharge in North Dakota for the Scenarios B1, A2, and A1B in Future Periods}

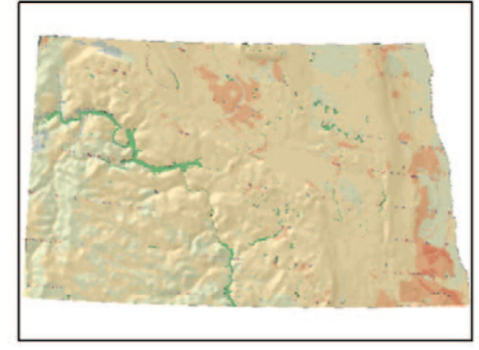

B1: Year 2020

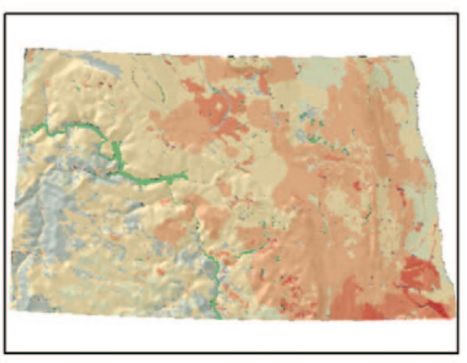

B1: Year 2050

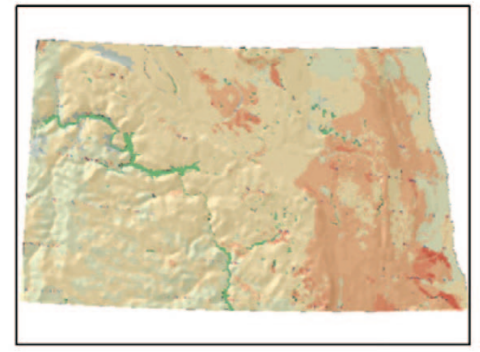

A1B: Year 2020

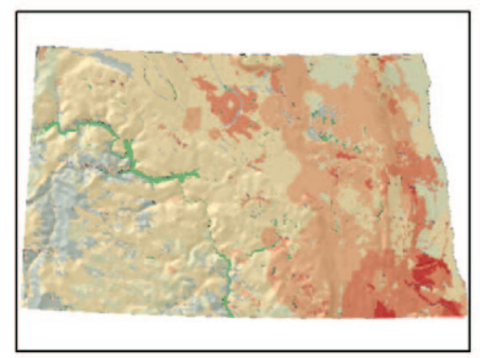

A1B: Year 2050

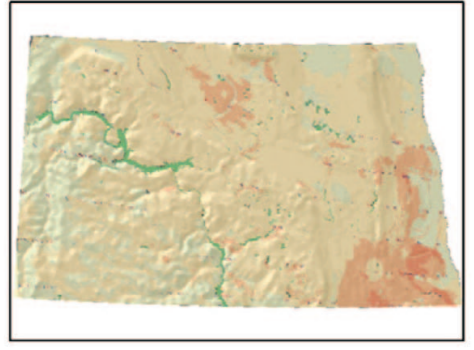

A2: Year 2020

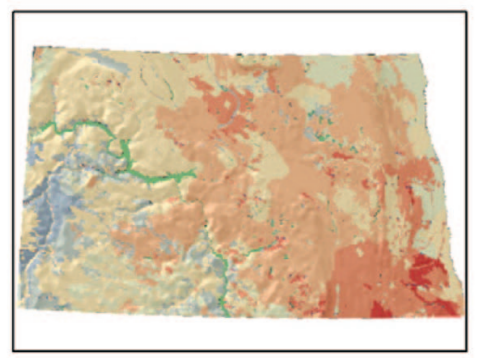

A2: Year 2050

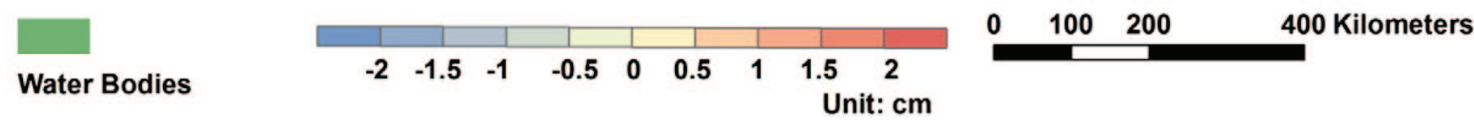

Figure 6. Projected groundwater recharge change in North Dakota. The changes are relative to the baseline period (year 2000).

Table 3. Areas of biofuels-related crops under different future scenarios in North Dakota (unit: $10^{3}$ ha).

\begin{tabular}{|c|c|c|c|c|}
\hline \multirow[t]{2}{*}{ Scenarios } & \multicolumn{4}{|l|}{ Ecoregion } \\
\hline & $\begin{array}{l}\text { Lake Agassiz } \\
\text { Plain }\end{array}$ & $\begin{array}{l}\text { Northern } \\
\text { Glaciated Plains }\end{array}$ & $\begin{array}{l}\text { Northwestern } \\
\text { Glaciated Plains }\end{array}$ & $\begin{array}{l}\text { Northwestern } \\
\text { Great Plains }\end{array}$ \\
\hline B1: year 2020 & 1547.33 & 2745.90 & 227.25 & 0.00 \\
\hline A2: year 2020 & 1156.95 & 1757.03 & 14.40 & 0.00 \\
\hline B1: year 2050 & 1590.53 & 3150.90 & 319.05 & 0.00 \\
\hline A1B: year 2050 & 1573.88 & 2727.00 & 78.30 & 0.00 \\
\hline A2: year 2050 & 1296.00 & 1652.40 & 17.78 & 0.00 \\
\hline A2: changes during $2020-2050$ & 139.05 & -104.63 & 3.38 & 0 \\
\hline
\end{tabular}

ergy described in the basic scenarios. Under the B1 scenario, high demands for cleaner energy, especially biofuels, would tend to favor expansion of lands devoted to corn and soybean production. By contrast, under the A2 scenario, the socio-economic priority is to meet food demands of an increasing population rather than demands for cleaner energy. Therefore, LULC change would tend to result in additional areas devoted to food crops such as wheat rather than to biofuel crops alone; thus, the area of corn and soybeans under the A2 scenario would likely be lower than under the B1 scenario.

\subsection{Future recharge scenarios}

Climate change is forecasted to impact groundwater recharge more strongly in southeastern North Dakota than in other regions with increases in ranging from 1.5 to $2 \mathrm{~cm}$. According to Equation (1), projected future precipitation patterns are critical to the differences in recharge among the $\mathrm{B} 1, \mathrm{~A} 2$ and $\mathrm{A} 1 \mathrm{~B}$ scenarios. The high- est changes in recharge have been projected to occur for the $\mathrm{A} 1 \mathrm{~B}$ scenario in 2020 and for the A2 scenario in 2050 since the A1B and A2 scenarios correspond to the largest increases in precipitation during these two periods respectively (Figure 6). This difference may be explained by the IPCC modeling results: the A1B scenario is associated with the highest warming trend at the earlier period of the 21st century, but then the A1b scenario is superseded by the A1B scenario.

\subsection{Future DTW scenarios}

Most parts of Eastern North Dakota are projected to have rising water tables (increasing 5-15 cm) in 2020 and 2050 under all scenarios. In 2020, the A1B scenario shows the largest increase in groundwater level in response to the highest increase in groundwater recharge (see Figure 7). The A2 scenario showed the largest increase in groundwater level in 2050 because groundwater recharge is greatest under the A2 scenario in the same period (Fig- 


\section{Depth-to-Water Change in North Dakota for the Scenarios B1, A2, and A1B in Future Periods}

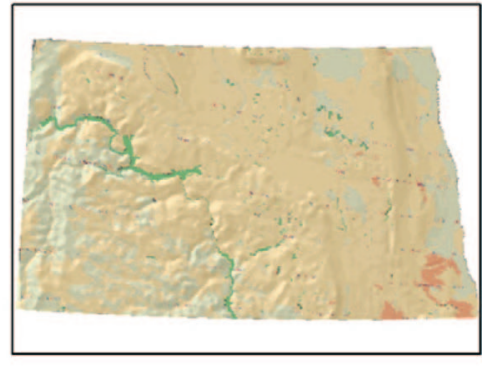

B1: Year 2020

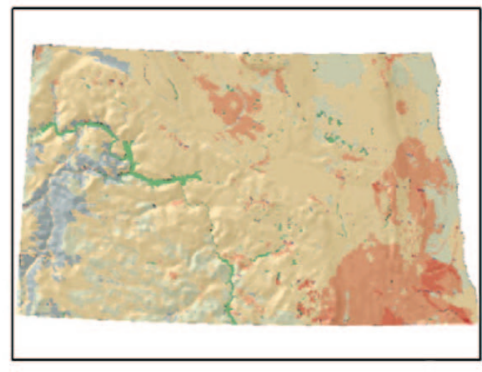

B1: Year 2050

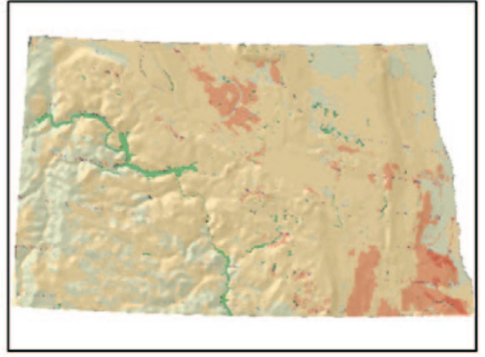

A1B: Year 2020

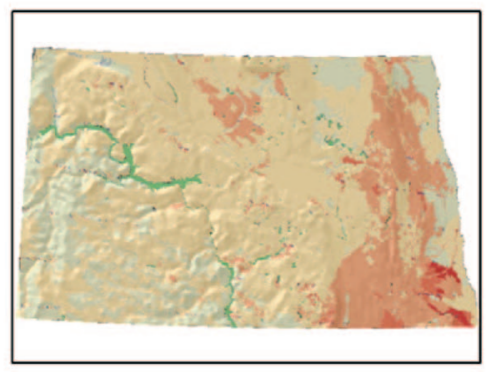

A1B: Year 2050

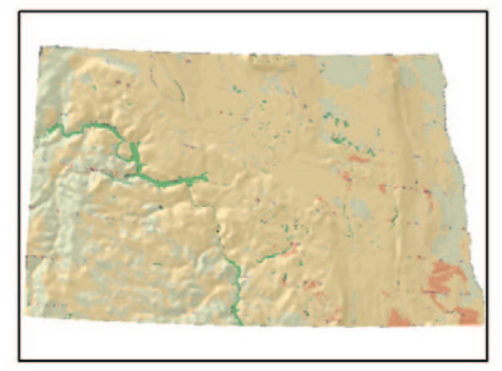

A2: Year 2020

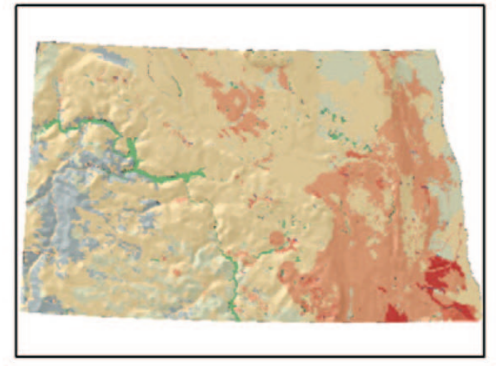

A2: Year $\mathbf{2 0 5 0}$

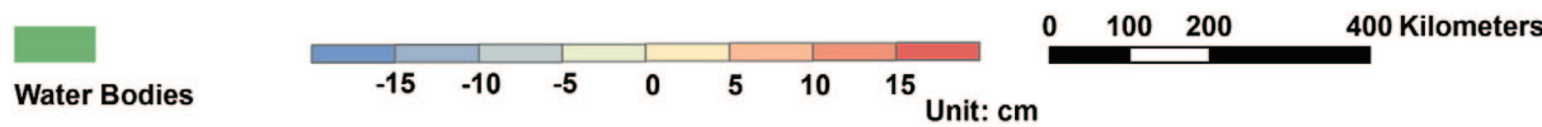

Figure 7. Projected DTW change in North Dakota. The changes are relative to the baseline period (year 2000).

ure 7). The differences in DTW among the B1, A2 and A1B scenarios can be explained by the differing projected future precipitation patterns. Increases (or decreases) in precipitation can enhance (or reduce) water recharged to the aquifer, and hence elevate (or diminish) groundwater levels.

\subsection{Modeled current and future groundwater vulnerability patterns}

Baseline and future conditions of groundwater vulnerability in North Dakota are portrayed in Figures $8 \& 9$. For the baseline period (year 2000), the areas with the highest groundwater vulnerability were primarily in southeastern North Dakota. To validate the modeled groundwater vulnerability in the baseline period, observed nitrate concentrations from groundwater quality monitoring wells were compared with modeled vulnerability ratings at well locations (see Figure 8). The boxplot of nitrate- $\mathrm{N}$ concentrations by groundwater vulnerability ratings shows that the detected nitrate concentration increased with the vulnerability rating overall (Figure 10) and the mean values of these groups are significantly different based on an ANOVA test ( $p$-value < 0.05). Note that wells having zero nitrate concentration (around 1/3 of total wells) were excluded from the boxplot due to a focus on the contamination incidence. Note that the nitrate concentration did not correspond well with the areas of high and very high vulnerability in the boxplot, since there were only a very small number (6) of wells with detected concentration of $0.02 \mathrm{mg} / \mathrm{L}$ and no well fell into the areas with high and very high vulnerability, respectively. This reflects the limited availability and spatially clustering of wells as shown in Figure 8.

Groundwater vulnerability patterns are, of course, expected to shift significantly under all future scenarios. The greatest increases in groundwater pollution potential are projected to occur in the
Lake Agassiz Plain and Northern Glaciated Plains ecoregions. Thus, Eastern North Dakota may face higher groundwater pollution risk in the near future. Under almost all future scenarios, areas with moderate, high and very high vulnerability will dramatically expand, and areas with low or very low vulnerability will substantially shrink (Table 4). As shown in Figure 9 and Table 4, areas with high and very high groundwater pollution potential show the greatest increase under the B1 scenario. This is most likely attributable to expanded cultivation of corn and soybeans associated with higher fertilizer inputs and nitrate leaching potentials. The A2 scenario shows somewhat lower groundwater pollution risks overall, perhaps due to smaller areal expansion of corn and soybeans.

The observed similarities between patterns of groundwater vulnerability and biofuels-related land use (Figures 9 \& 5) may be explained by the high weights assigned to the land use factor. For the $\mathrm{B} 1, \mathrm{~A} 2$, and $\mathrm{A} 1 \mathrm{~B}$ scenarios, respectively, the increase in groundwater vulnerability between 2020 and 2050 is not as significant as that between 2000 and 2020, because biofuels-related cropland in North Dakota is projected to increase most rapidly from 2000 to around 2020, and then slow down after 2020 (as shown in Figure 9).

\subsection{Sensitivity analysis}

A sensitivity analysis was conducted to assess how the uncertainties of future climate change and associated DTW, recharge and land use could affect modeled groundwater pollution risk. The analysis evaluated overall model responsiveness to a specific factor using the following equation.

$$
\mathrm{V} \%=\frac{\mathrm{V}(\mathrm{x})-\mathrm{V}}{\mathrm{V}} \times 100 \%
$$




\section{Groundwater Vulnerability in North Dakota for the Current Period (Year 2000)}

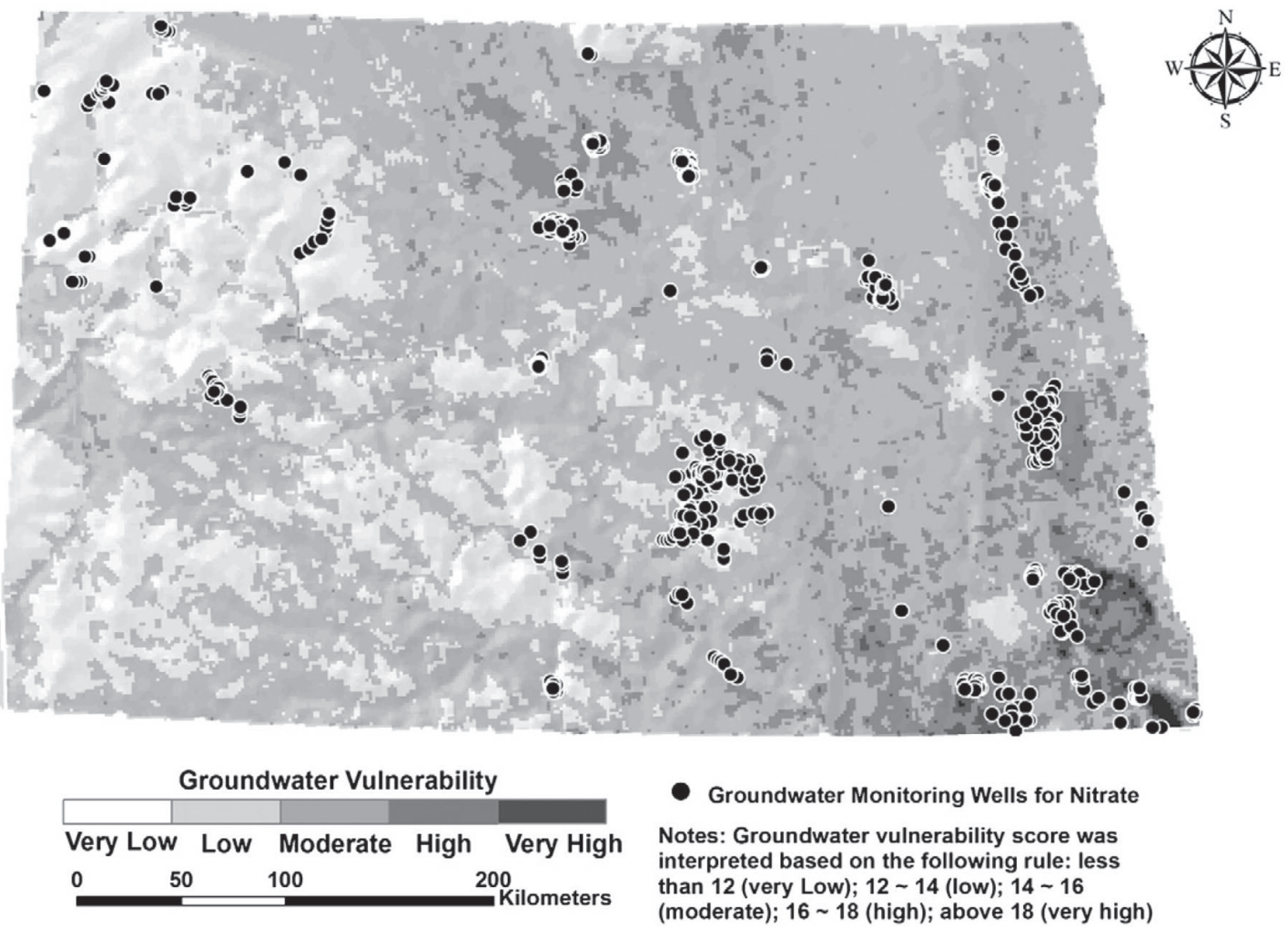

Figure 8. Groundwater vulnerability in North Dakota for the baseline period.

\section{Groundwater Vulnerability in North Dakota for the Scenarios B1, A2, and A1B in Future Periods (Year 2020 and Year 2050)}

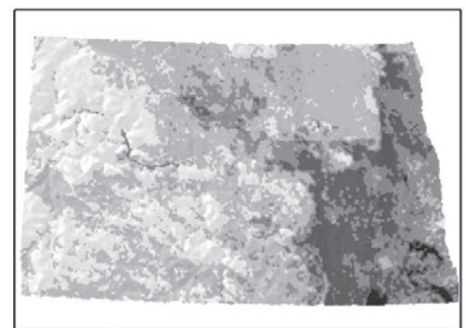

B1: Year 2020

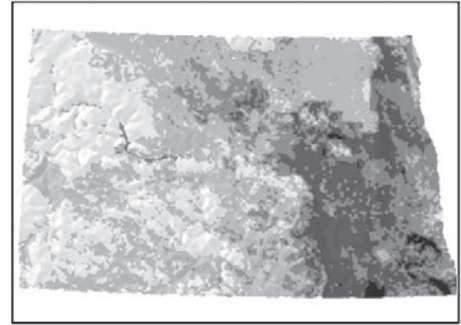

B1: Year 2050

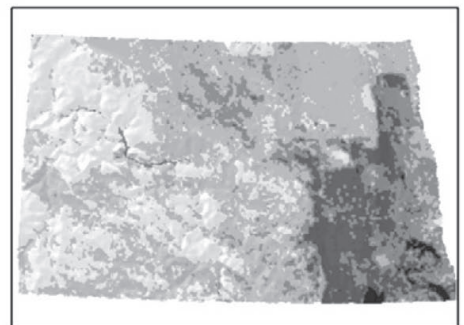

A1B: Year 2020

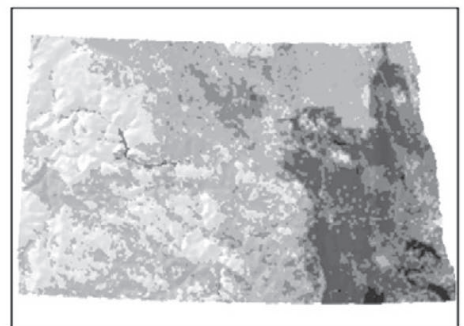

A1B: Year 2050

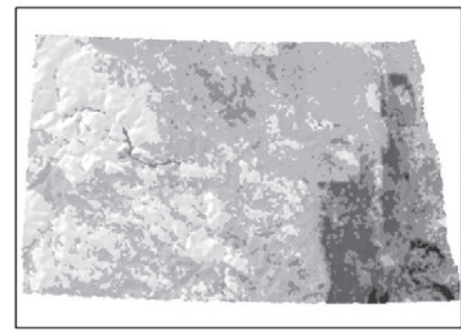

A2: Year 2020

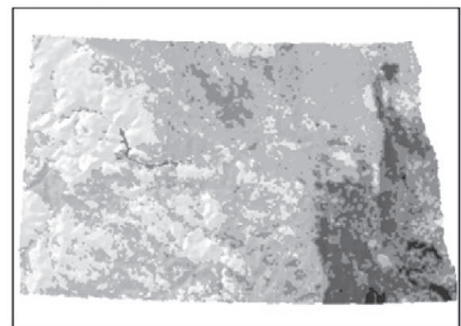

A2: Year 2050

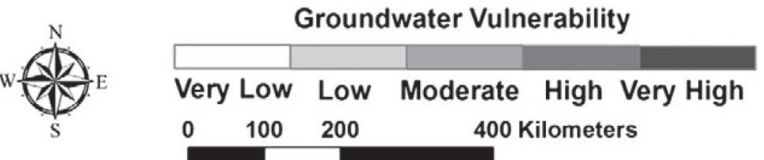

Notes: Groundwater vulnerability score was interpreted based on the following rule: less than 12 (very Low) $12 \sim 14$ (low); $14 \sim 16$ (moderate); $16 \sim 18$ (high); above 18 (very high)

Figure 9. Projected groundwater vulnerability in North Dakota. 


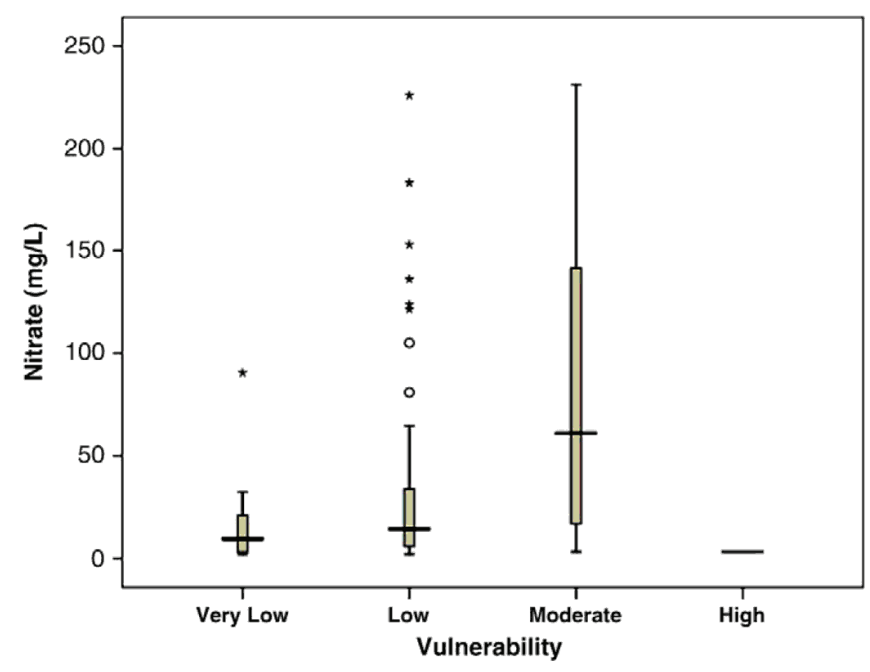

Figure 10. Boxplot of nitrate-N concentrations by groundwater vulnerability. Data were retrieved from the North Dakota State Water Commission Surface and Ground Water Data Portal.

where $\mathrm{V} \%$ is the variation of groundwater vulnerability expressed as a percentage, $\mathrm{V}(\mathrm{x})$ stands for the vulnerability affected by changes in specific factor $\mathrm{x}$ (e.g. DTW, recharge), and $\mathrm{V}$ is the vulnerability score value computed before reclassification.

Table 5 shows the statistical summary of changes in groundwater vulnerability due to changes in DTW, recharge and land use under the B1, A1B and A2 scenarios for 2020 and 2050. Mean, minimum, maximum and standard deviation indicate the average, smallest, largest values and standard deviation of groundwater vulnerability variations over the entire study area by varying DTW, recharge and land use in order. Overall, variations of groundwater vulnerability caused by changes in land use are much more significant than those caused by changes in DTW and recharge. The effects of changes in DTW on variations in groundwater vulnerability are greater than those caused by changes in recharge. Since changes in DTW and recharge reflect climate conditions and land use change is mainly attributable to anthropogenic activities, this sensitivity analysis indicates that anthropogenic land use factors may dominate changes in groundwater vulnerability in North $\mathrm{Da}-$ kota. This is consistent with previous research that has shown that the impact of LULCC on the hydrologic system may surpass that of recent or anticipated climate change at least over decadal time scales (Vorosmarty et al., 2004).

We conclude, therefore, that the land use factor is more influential than DTW and recharge on the predicted future groundwater vulnerability in North Dakota under all 6 future scenarios. Greater emphasis should be placed on modeling of biofuels-related land use change in a study of future groundwater vulnerability in response to future climate and land use change.

\subsection{Limitations}

In this study, future changes in groundwater vulnerability were modeled as the effects of a combination of climate-related socioeconomic scenarios, climate change, and biofuels-related cropland change. These factors were combined in a linear model to forecast changes in groundwater vulnerability. However, it is recognized that the actual physical processes of groundwater contamination are not linear, but involve complex mechanisms such as pollutant transport and dilution, adsorption on soil particles, and chemical and biological degradation. Thus, the model used in this study may over- or under-estimate groundwater pollution risk. Still, the linear modeling approach has a significant advantage in that it simplifies complex groundwater contamination processes and can facilitate rapid regional evaluation based on well-recognized key hydrogeologic factors. Such evaluation can be very difficult using physical models which typically require complex parameterization of hydrologic processes and considerable computing resources. The relationships between predictive factors and modeled groundwater vulnerability also follow valid hydrogeologic principles, e.g. smaller DTW indicating higher chance of contaminants reaching the groundwater.

It should be noted that the groundwater vulnerability maps developed for this research portray only the "risk" of pollution on a regional scale, and cannot be used to interpret incidences of actual local groundwater contamination. Note that site-specific factors, such as hydraulic fracturing for shale oil in western North Dakota, which may cause drinking water contamination (Mayda, 2011), were not considered.

The results of this research may also be affected significantly by uncertainties related to climate change projections. Impacts of climate change on the fate and transport of pollutants tend to be highly variable and difficult to predict because of the uncertainties associated with climate predictions (Bloomfield et al., 2006). Projections of climate change models (e.g., regarding future precipitation and temperature patterns) can vary significantly, especially in the northern Great Plains. The so-called line of zero change (i.e. the boundary where no change in precipitation occurs over the modeling periods) is oriented more or less west-to-east in this region (Christensen et al., 2007) for different models. The study area is predicted to be drier by some models (e.g. MIROC3.2.medres), while wetter by some other models (e.g. CGCM3.1.T63). The multi-model mean of climate projections used in this study may vary its spatial pattern, depending on the number of climate projections included for averaging. Therefore, great variability in climate projections is inherent in this study, and may affect groundwater vulnerability patterns. In addition, the modeling results are also

Table 4. Areas of different vulnerability categories and percent change during the modeling period in North Dakota (unit: $10^{3}$ ha).

\begin{tabular}{|c|c|c|c|c|c|}
\hline \multirow[t]{2}{*}{ Scenarios } & \multicolumn{5}{|c|}{ Vulnerability categories } \\
\hline & Very low & Low & Moderate & High & Very high \\
\hline Baseline: 2000 & 5610.75 & 10964.87 & 1672.30 & 173.50 & 30.19 \\
\hline B1: year 2020 & 5440.95 & 7750.80 & 3086.78 & 2059.43 & 113.63 \\
\hline A1B: year 2020 & 5463.00 & 8412.30 & 2652.30 & 1804.28 & 119.70 \\
\hline A2: year 2020 & 5649.30 & 9192.38 & 2265.53 & 1245.83 & 98.55 \\
\hline B1: year 2050 & 5226.30 & 7294.50 & 3258.00 & 2531.48 & 141.30 \\
\hline A1B: year 2050 & 5389.88 & 7849.80 & 2789.55 & 2286.45 & 135.90 \\
\hline A2: year 2050 & 5510.03 & 9103.28 & 2329.65 & 1390.95 & 117.68 \\
\hline B1: changes during 2000-2020 & -169.80 & -3214.07 & 1414.48 & 1885.92 & 83.43 \\
\hline A1B: changes during 2000-2020 & -147.75 & -2552.57 & 980.00 & 1630.77 & 89.51 \\
\hline A2: changes during 2000-2020 & 38.55 & -1772.49 & 593.23 & 1072.32 & 68.36 \\
\hline B1: changes during 2020-2050 & -954.00 & -2028.00 & 761.00 & 2098.00 & 123.00 \\
\hline A1B: changes during $2020-2050$ & -325.00 & -2500.00 & 610.00 & 2143.00 & 72.00 \\
\hline A2: changes during $2020-2050$ & -619.00 & -396.00 & 285.00 & 645.00 & 85.00 \\
\hline
\end{tabular}


Table 5. Statistics for sensitivity analysis using cells covering the entire modeling area.

\begin{tabular}{|c|c|c|c|c|c|}
\hline \multirow[t]{2}{*}{ Parameters } & & \multicolumn{4}{|l|}{ Variation } \\
\hline & & Mean & Min. & Max. & S.D. \\
\hline \multirow[t]{3}{*}{ B1 2020} & DTW & $-1.4 \%$ & $-14.7 \%$ & $10 \%$ & 0.003 \\
\hline & Recharge & $0.1 \%$ & $-4.0 \%$ & $5.6 \%$ & 0.006 \\
\hline & Land use & $5.5 \%$ & $-40.4 \%$ & $78.7 \%$ & 0.134 \\
\hline \multirow[t]{3}{*}{ A1B 2020} & DTW & $-1.4 \%$ & $-14.7 \%$ & $10 \%$ & 0.003 \\
\hline & Recharge & $0.3 \%$ & $-4.0 \%$ & $6.3 \%$ & 0.007 \\
\hline & Land use & $4.5 \%$ & $-40.4 \%$ & $78.7 \%$ & 0.125 \\
\hline \multirow[t]{3}{*}{ A2 2020} & DTW & $-1.4 \%$ & $-14.7 \%$ & $10 \%$ & 0.003 \\
\hline & Recharge & $0.1 \%$ & $-4.1 \%$ & $5.4 \%$ & 0.006 \\
\hline & Land use & $3.2 \%$ & $-40.4 \%$ & $78.7 \%$ & 0.113 \\
\hline \multirow[t]{3}{*}{ B1 2050} & DTW & $-1.4 \%$ & $-14.6 \%$ & $10 \%$ & 0.003 \\
\hline & Recharge & $0.6 \%$ & $-6.4 \%$ & $9.1 \%$ & 0.014 \\
\hline & Land use & $6.4 \%$ & $-40.4 \%$ & $78.7 \%$ & 0.140 \\
\hline \multirow[t]{3}{*}{ A1B 2050} & DTW & $-1.4 \%$ & $-14.7 \%$ & $10 \%$ & 0.003 \\
\hline & Recharge & $0.5 \%$ & $-4.5 \%$ & $7.1 \%$ & 0.010 \\
\hline & Land use & $5.3 \%$ & $-40.4 \%$ & $78.7 \%$ & 0.132 \\
\hline \multirow[t]{3}{*}{ A2 2050} & DTW & $-1.4 \%$ & $-14.6 \%$ & $10 \%$ & 0.003 \\
\hline & Recharge & $0.6 \%$ & $-5.5 \%$ & $7.6 \%$ & 0.013 \\
\hline & Land use & $3.2 \%$ & $-40.4 \%$ & $78.7 \%$ & 0.113 \\
\hline
\end{tabular}

subject to the uncertainty from resampling of the relatively coarse resolution climate data (best available at 0.125 -degree resolution) to finer resolution (at $1500 \mathrm{~m}$ ). And, the study did not consider climate variability over short periods, which may also be critical to groundwater contamination. For example, variations in temperature and precipitation association with ENSO (El Niño Southern Oscillation) and PDO (Pacific Decadal Oscillation) over short periods can influence the amount of water that recharges aquifers (Toews and Allen, 2009). Such variability may result in greater climate extremes and considerable shifts to the mean climate conditions, and hence add more uncertainties to the projections of biofuels-related land use, recharge, DTW and groundwater vulnerability. These climate cycles, due to their high unpredictability, were not considered in current climate change projections.

In addition to climate change, uncertainties associated with biofuels-related cropland modeling, groundwater level and recharge modeling may also be crucial to the results. For example, biofuelsrelated cropland change is modeled cell-by-cell under the assumption that such cells have at least $40 \%$ of their area in cultivated corn and/or soybeans (see Li et al., 2012). When assigning rating and weighting values, these cells are treated as if they were $100 \%$ corn and/or soybeans. Thus, the vulnerability scores of some cells are almost certainly overestimated.

\section{Summary and Conclusions}

Changes in groundwater vulnerability patterns are the result of human-environment-climate interactions across a range of spatial and temporal scales. In this study, climate change scenarios, a land use change model, a recharge estimation model, and a groundwater vulnerability model were integrated in a GIS framework to map future groundwater vulnerability patterns in North Dakota. The "backbone" of this framework is DRSTIL (a modified DRASTIC model). In spite of limitations mentioned above, the modeling approach used here appears well-suited for linking groundwater vulnerability with climate and land use change at the regional scale. The proposed methodological framework can potentially be applied in most areas of the U.S. Northern Great Plains, because all of the related parameters were developed using international, U.S. national and/or statewide datasets.

This research suggests that groundwater vulnerability in the northern Great Plains will be impacted by projected climate change and biofuels-related land use change. The modeling results have shown that, under all future scenarios examined, most parts of eastern North Dakota will be increasingly vulnerable to groundwa- ter contamination from nitrates. The results indicate that the largest increase in groundwater pollution risk will occur under the B1 scenario, while under the A2 scenario pollution risks will increase least. Note that under the B1 scenario, a quality environment and clean energy are highly preferred, and expansion of biofuel crops for bioethanol and biodiesel could be expected as a response to encourage reduction of carbon dioxide. Although the A2 scenario assumes high demographic pressure and high fossil fuel usage, lower demands for biofuel crops tend to discourage fast expansion of corn and soybeans, thus reducing nitrate pollution stemming from fertilizers.

The study also suggests that biofuel crops, traditionally regarded as climate friendly (Powlson et al., 2005), may act as a double-edged sword. With biofuel crops displacing other crops such as wheat and alfalfa in North Dakota, there may be a significant increase in fertilizer inputs to the farm lands. Thus, the fast development of biofuels-related cropland may not be sustainable from an environmental perspective. A recent field study conducted in southeastern North Dakota showed that increases in nitrate application rates can significantly elevate nitrate concentrations in the shallow groundwater in this area (Derby et al., 2009). Thus, increasing risks of groundwater pollution may be associated with the expansion of biofuel crops. Natural resources managers will likely need to target protection strategies and measures such as regulating application of farm chemicals and installing monitoring wells in areas prone to high groundwater pollution risk. Although this research was conducted in North Dakota, it clearly could be adapted and applied in other similar agricultural regions undergoing significant climate change and rapid land use change.

This research could, perhaps, aid groundwater managers in selecting and prioritizing sites for future groundwater monitoring and protection. For areas predicted to have elevated groundwater pollution risk, appropriate agricultural policies/practices may be imperative to prevent groundwater contamination. The results from this research may also help promote dialog and improve decision-making on biofuels incentives, polices and laws (Simpson et al., 2008; Koshel et al., 2010) by incorporating groundwater pollution risk and concerns.

Future research should include testing this modeling approach in other locales. In addition, it is recommended that the narrative descriptions of SRES scenarios and statistical extrapolation of historical cropland data be augmented by information on biofuel policies and food security.

Acknowledgments - We gratefully acknowledge the financial support for this research provided by the School of Natural Resources and the Center for Advanced Land Management Information Technologies, University of Nebraska-Lincoln (UNL). We also would like to thank UNL professors Dr. Xun-Hong Chen, Dr. Qingfeng Guan, Dr. David Gosselin, and Dr. Robert Oglesby for their valuable comments and suggestions in developing this paper. We greatly appreciate the climate change scenario data provided by Dr. Song Feng, UNL. We also would like to thank the anonymous reviewers for Science of The Total Environment for their valuable comments and suggestions to improve this paper.

\section{References}

Aller L, Bennett T, Lehr JH, Petty RJ. DRASTIC—a standardized system for evaluating ground water pollution potential using hydrogeologic settings. U.S. Environmental Protection Agency, U.S. Environmental Protection Agency report. EPA/600/2-85/018. Washington, D.C.; 1985.

Arnell NW. Climate change and water resources in Britain. Clim Chang 1998;39(1): 83-110.

Barrett JE, Burke IC. Nitrogen retention in semiarid ecosystems across a soil organic-matter gradient. Ecol Appl 2002;12(3):878-90.

Bates BC, Kundzewicz ZW, Wu S, Palutikof JP, editors. Climate change andwater. Technical Paper VI of the IPCCGeneva: IPCC Secretariat; 2008. 
Bloomfield J, Williams R, Gooddy D, Cape J, Guha P. Impacts of climate change on the fate and behaviour of pesticides in surface and groundwater-a UK perspective. Sci Total Environ 2006;369:163-77.

Bowen CR, Hollinger SE. Alternative crops web site, Illinois State Water Survey, Champaign, IL. Online Retrieved January 13, 2010 from http://www.isws.illinois.edu/data/altcrops/docs/AltCropsModel2004.pdf

Braun GM, Levine NS, Roberts SJ, Samel AN. A geographic information systems methodology for the identification of groundwater recharge areas in Waukesha County, Wisconsin. Environ Eng Geosci 2003;9:267-78.

Brooke R, Fogel G, Glaser A, Griffin E, Johnson K. How increases in corn plantings are affecting habitat and wildlife in the Prairie Pothole Region. A University of Michigan study published by the Natural Wildlife Federation; 2009.

Burkart MR. Ground-water resources of Sheridan County, North Dakota. North Dakota State Water Commission County Ground-Water Studies 32, pt. III, and North Dakota Geological Survey Bulletin 75; 1981. (pt. III, 32 pp.)

Butscher C, Huggenberger P. Modeling the temporal variability of karst groundwater vulnerability, with implications for climate change. Environ Sci Technol 2009;43: 1665-9.

Chen Z, Grasby S, Osadetz K. Predicting average annual groundwater levels from climatic variables: an empirical model. J Hydrol 2002;260:102-17.

Christensen JH, Hewitson B, Busuioc A, Chen A, Gao X, Held I, et al. Regional climate projections. In: Solomon S, Qin D, Manning M, Chen Z, Marquis M, Averyt KB, Tignor M, Miller HL, editors. Climate change 2007: The physical science basis. Contribution of Working Group I to the Fourth Assessment Report of the Intergovernmental Panel on Climate Change. Cambridge, United Kingdom and New York, NY, USA: Cambridge University Press; 2007.

Croley TE, Luukkonen CL. Potential effects of climate change on ground water in Lansing, Michigan. J Am Water Resour Assoc 2003;39:149-63.

Dams J, Woldeamlak ST, Batelaan O. Forecasting land-use change and its impact on the groundwater system of the Kleine Nete catchment, Belgium. Hydrol Earth Syst Sci Discuss 2007;4:4265-95.

de Oliveira MED, Vaughan BE, Rykiel Jr EJ, et al. Ethanol as fuel: energy, carbon dioxide balances, and ecological footprint. Bioscience 2005;55:593-603.

Derby NE, Casey FXM, Knighton RE. Long-term observations of vadose zone and groundwater nitrate concentrations under irrigated agriculture. Vadose Zone J 2009;8(2): 290-300.

Ducci D. Influence of climate changes on vulnerability maps. Presented at the first conference and workshop on "groundwater and climate change" held in Norwich, UK, University of East Anglia; April 4-6, 2005.

Eckhardt DA, Stackelberg PE. Relation of ground-water quality to land use on Long Island, New York. Ground Water 1995;33(6):1019-33.

Eckhardt K, Ulbrich U. Potential impacts of climate change on groundwater recharge and streamflow in a central European low mountain range. Journal of Hydrology 2003;284:244-52.

Economic Research Service (in U.S. Department of Agriculture). North Dakota fact sheet. Online retrieved on July 12, 2011 at http://www. ers.usda.gov/Data/FarmIncome/FinfidmuX1s.htm2011

Foley JA, Kucharik CJ, Twine TE, Coe MT, Donner SD. Land use, land cover and climate change across the Mississippi basin: impacts on selected land and water resources. In: DeFries R, et al, editor. Ecosystems and land use changeGeophys Monogr Ser 2004;153:249-61.

Focazio MJ, Reilly TE, Rupert MG, Helsel DR. Assessing ground-water vulnerability to contamination: providing scientifically defensible information for decision makers, U.S. Geological Survey Circular 1224. Online at http://pubs.usgs.gov/circ/2002/circ1224/

Franzen D. North Dakota fertilizer recommendation tables and equations (rev.). Fargo, North Dakota: NDSU Extension Service: North Dakota State University; 2009.
Frederick CL. Ground water pollution potential of Ross County, Ohio. Ohio Department of Natural Resources, Division of Water, Columbus, OhioGroundwater pollution potential report, No. 24, 1991 (400 pp.)

Gogu RC, Dassargues A. Current trends and future challenges in groundwater vulnerability assessment using overlay and index methods. Environ Geol 2005;39:549-59.

Graham RL. Forecasting the magnitude of sustainable biofeedstock supplies: the challenges and the rewards. Biofuels Bioprod Bioref 2007;1:255-63.

Green TR, Taniguchi M, Kooi H, Gurdak JJ, Allen DM, Hiscock KM, et al. Beneath the surface of global change: impacts of climate change on groundwater. Journal of Hydrology 2011;405:532-60.

Hall ND, Stuntz BB, Abrams RH. Climate change and freshwater resources. Nat Resour Environ 2008;22(3):30-5.

Hamza M, Added A, Rodríguez R, Abdeljaoued S, Ben Mammou A. A GIS-based DRASTIC vulnerability and net recharge reassessment in an aquifer of a semi-arid region (Metline-Ras Jebel-RafRaf Aquifer, Northern Tunisia). J EnvironManage 2007;84:12-9.

Holman IP. Climate change impacts on groundwater recharge uncertainty, shortcomings, and the way forward? Hydrogeol J 2005;14(5):637-47.

Ige DV, Akinremi OO, Flaten DN. Direct and indirect effects of soil properties on phosphorus retention capacity. Soil Sci Soc Am J 2007;71:95-100.

Intergovernmental Panel on Climate Change (IPCC). Climate change 2007: synthesis report. In: Writing Team Core, Pachauri RK, Reisinger A, editors. Contribution of working groups I, II and III to the fourth assessment report of the intergovernmental panel on climate change. Geneva, Switzerland: IPCC; 2007. (104 pp.)

Jia X, Scherer TF, Steele DD. Crop water requirement for major crops in North Dakota and its vicinity area. ASABE Red River Valley section meeting paper no. RRV-07133, 2007 St Joseph, MI: American Society of Agricultural and Biological Engineers.

Karkouti K, Djaiani G, Borger MA, Beattie WS, Fedorko L, Wijeysundera $\mathrm{D}$, et al. Low hematocrit during cardiopulmonary bypass is associated with increased risk of perioperative stroke in cardiac surgery. Ann Thorac Surg 2005;80(4):1381-7.

Kennedy D. The biofuels conundrum. Science 2007;316(5824):515.

Knobeloch L, Salna B, Hogan A, Postle J, Anderson H. Blue babies and nitrate-contaminated well water. Environ Health Perspect 2000;108(7):675-8.

Koshel P, McAllister K, National Research Council. Expanding biofuel production and the transition to advanced biofuels. Washington D.C.: National Academies Press; 2010

Kravchenko AN, Bullock DG. Correlation of corn and soybean grain yield with topography and soil properties. Agron J 2000;92:75-83.

Li R, Guan Q, Merchant J. A geospatial modeling framework for assessing biofuels-related land-use and land-cover change. Agric Ecosyst Environ 2012;161:17-26.

Lima ML, Zelaya K,Massone H. Groundwater vulnerability assessment combining the drastic and dyna-Clue model in the Argentine pampas. Environ Manage 2011;47:828-39.

Loaiciga HA, Valdes JB, Vogel R, Garvey J, Schwarz H. Global warming and the hydrologic cycle. Journal of Hydrology 1996;174:83-127.

Masetti M, Sterlacchini S, Ballabio C, Sorichetta A, Poli S. Influence of threshold value in the use of statistical methods for groundwater vulnerability assessment. Sci Total Environ 2009;407:3836-46.

Maurer EP, Brekke L, Pruitt T, Duffy PB. Fine-resolution climate projections enhance regional climate change impact studies. Eos Trans 2007;AGU 88(47):504.

Mayda C. The booms and busts of Noonan, North Dakota. Focus Geogr 2011;54(4):152.

Meehl A, Covey C, Delworth T, Latif M, McAvaney B, Mitchell JFB, et al. The WCRP CMIP3 multimodel dataset: a new era in climate change research. Bull Am Meteorol Soc 2007;88:1383-94.

Meehl GA, Hibbard K. A strategy for climate change stabilization ex- 
periments with AOGCMs and ESMs. Aspen Global Change Institute 2006 session. Earth system models: the next generation (Aspen, Colorado, July 30-August 5, 2006). Aspen, USA: International Geosphere-Biosphere Programme; 2007. p. 37.

Merchant JM. GIS-based groundwater pollution hazard assessment: a critical review of the DRASTIC model. Photogramm Eng Remote Sens 1994;60(9):1117-27.

Nakicenovic N, Alcamo J, Davis G, de Vries B, Fenhann J, Gaffin S, et al. Special report on emissions scenarios. Cambridge: Cambridge University Press; 2000. p. 599.

National Agricultural Statistics Service. Acreage. Retrieved August 5, 2010 from http://usda.mannlib.cornell.edu/MannUsda/viewDocumentInfo.do?documentID $=1000$

National Research Council. Groundwater vulnerability assessment: contamination potential under conditions of uncertainties. Washington, D.C: National Academy Press; 1993. p. p. 185.

National Research Council. Water implications of biofuels production in the United States. Washington D.C.: The National Academies Press; 2008; online at $\mathrm{http}: / /$ dels.nas.edu/dels/rpt briefs/biofuels brief final.pdf

Neukum C, Azzam R. Quantitative assessment of intrinsic groundwater vulnerability to contamination using numerical simulations. Sci Total Environ 2009;408:245-54.

Nolan BT, Hitt KJ, Ruddy BC. Probability of nitrate contamination of recently recharged groundwaters in the conterminous United States. Environ Sci Technol 2002;36(10): 2138-45.

Ojima D, Garcia L, Elgaali E, Miller K, Kittel TGF, Lackett J. Potential climate change impacts on water resources in the Great Plains. J AmWater Resour Assoc 1999;35(6):1443-54.

Omernik JM. Ecoregions of the conterminous United States. Ann Assoc Am Geogr 1987;77(1):118-25.

Paulson QF. Guide to North Dakota's ground-water resources. U.S. Geological Survey Water-Supply Paper 2236, Reston, VA, USA; 1983.

Pointer C. Groundwater and climate change. Report on the IAH working group of groundwater and climate change meeting, University of East Anglia, Norwich, UK; April 4-6, 2005.

Power J, Schepers J. Nitrate contamination of groundwater in North America. Agric Ecosyst Environ 1989;26:165-87.

Powlson DS, Riche AB, Shield I. Biofuels and other approaches for decreasing fossil fuel emissions from agriculture. Ann Appl Biol 2005;146:193-201.

Rahman A. A GIS based DRASTIC model for assessing groundwater vulnerability in shallow aquifer in Aligarh, India. Appl Geogr 2008;28(1):32-53.

Rasmussen WC, Andreason GG. Hydrologic budget of the Beaver Dam Creek Basin, Maryland. U S Geol Surv Water Supply Pap 1959;1472. (106 pp.)

Rosenzweig C, Casassa G, Karoly DJ, Imeson A, Liu C, Menzel A, et al. Assessment of observed changes and responses in natural and managed systems. Climate change 2007: impacts, adaptation and vulnerability. In: Parry ML, Canziani OF, Palutikof JP, van der Linden PJ, Hanson CE, editors. Contribution of working group II to the fourth assessment report of the intergovernmental panel on climate change. Cambridge, UK: Cambridge University Press; 2007. p. 79-p. 131.
Ruosteenoja K, Carter TR, Jylhä K, Tuomenvirta H. Future climate in world regions: an intercomparison of model-based projections for the new IPCC emissions scenarios. The Finnish Environment, 644. Finnish Environment Institute; 2003. p. 83.

Sampat P. Groundwater shock: the polluting of the world's major freshwater stores. World Watch 2000;13(1):10-22.

Scanlon BR, Jolly I, Sophocleus M, Zhang L. Global impacts of conversions from natural to agricultural ecosystems on water resources: quantity versus quality. Water Resour Res 2007;43:WO3437-8.

Schuh WM, Patch J. Retention of aquifer recharge and recovery water in a shallow unconfined aquifer: simulations of a basin recharge and recovery facility in Grand Forks County, North Dakota. North Dakota State Water Commission water resources investigation no. 48; 2009.

Scibek J, Allen DM. Modeled impacts of predicted climate change on recharge and groundwater levels. Water Resour Res 2006;42(11):1-18.

Simpson TW, Sharpley AN, Howarth RW, Paerl HW, Mankin KR. The new gold rush: fueling ethanol production while protecting water quality. J Environ Qual 2008;37(2):318-24.

Snyder DT. Estimated depth to ground water and configuration of the water table in the Portland, Oregon area. U.S. geological survey scientific investigations report 2008- 5059; 2008. Retrieved November 11, 2010, from http://pubs.usgs.gov/sir/2008/5059

Toews MW, Allen DM. Evaluating different GCMs for predicting spatial recharge in an irrigated arid region. Journal of Hydrology 2009;374:265-81.

Twarakavi NKC, Kaluarachchi JJ. Sustainability of ground water quality considering land use changes and public health risks. J Environ Manage 2006;81:405-19.

U.S. Department of Energy. North Dakota incentives and laws. Retrieved from http://www.afdc.energy.gov/afdc/laws/laws/ND\#Laws\%20 and $\% 20$ Regulations

U.S. Global Change Research Program. U.S. National assessment of the potential consequences of climate variability and change: A detailed overview of the consequences of climate change and mechanisms for adaptation, 2000; online at http:/www.usgcrp.gov/usgcrp/nacc/

Vorosmarty C, Lettenmaier D, Leveque C, Meybeck M, Pahl-Wostl C, Alcamo J, et al. Humans transforming the global water system. EOS Trans Am Geophys Union 2004;85(48):509-20.

Wallander S, Claassen R, Nickerson C. The ethanol decade: an expansion of U.S. corn production, 2000-09, EIB-79. U.S. Department of Agriculture, Economic Research Service; 2011.

Williams JR, Kissel DE. Water percolation: an indicator of nitrogenleaching potential. In: Follet RF, Keeney DR, Cruse RM, editors. Managing nitrogen for groundwater quality and farm profitability. Madison, Wisconsin: Soil Science Society of America, Inc.; 1991. p. 59-83.

Yang H, Xie Z. A new method to dynamically simulate groundwater table in land surface model VIC. Prog Nat Sci 2003;13(11):819-25.

Yu C, Yao Y, Hayes G, Zhang B, Zheng C. Quantitative assessment of groundwater vulnerability using index system and transport simulation, Huangshuihe catchment, China. Sci Total Environ 2010;408:6108-16 